\begin{tabular}{|l|c|c|c|}
\hline $\begin{array}{l}\text { ACTA CLASSICA } \\
\text { UNIV. SCIENT. DEBRECEN. }\end{array}$ & LII. & 2016. & \\
\hline
\end{tabular}

\title{
A COPTIC MAGICAL NAME IN A PANNONIAN PHYLACTERION
}

\author{
BY BENCE FEHÉR
}

\begin{abstract}
A silver lamella was found in Aquincum (1927/28), in a burial site which could be easily dated to the latest Trajan or early Hadrian era, but it was published defectively, misread and misinterpreted. Several attempts at re-interpretation in the 1990s and 2000s succeeded only partially. The reading I propose contains distinct textual units beginning with characters (among them hieroglyphs), and a Coptic magical logos ( $\pi \alpha \chi v o v(1 \zeta)$. In my opinion, the phylacterion was meant to give protection in the next world, and the writer of the spell was well acquainted with the Egyptian magical traditions.

Keywords: magic lamella, phylacterion, Coptic, characteres.
\end{abstract}

In these last years, a series of magical texts were found and published in Pannonia, and now we have a considerable corpus of these very interesting objects; but certainly we regarded the offensive magic (curse tablets, as recently from Aquincum and Savaria) with greater attention. ${ }^{1}$ Yet the objects of the defensive magic are probably more numerous: protective amulets, gems, and the most informative items, those phylacteria which were scratched onto metallic lamellas and closed in capsas. ${ }^{2}$

This kind of phylacteria is by no means less important than the curse tablets, but generally attracts less attention. An excellent example is the silver lamella, which was found in Aquincum, 1927/28. The circumstances were favourable: it was an excavation, the site (Bécsi street 166) and context is clearly identifiable, and the object was brought to the Museum of Aquincum in a relatively good condition (inv. n. AM 30236b).

\footnotetext{
${ }^{1}$ Barta 2009, Barta - Lassányi 2009, Barta 2012, Barta - Lassányi 2015, Barta 2016.

${ }^{2}$ Few such items were published from Pannonia, as for example CIGP 12-15, 111, 125, 152, TitAq III 1438, Bilkei 1979, 30, Kovács - Szabó 2006.

doi 10.22315/ACD/2016/7
} 
The lamella was found in a Roman grave, in its original bronze capsa, and the funeral was dated by a silver coin of Trajan from his later years. ${ }^{3}$ The coin was not worn, it could not be circulated but for a short time, therefore the deceased must have been buried at the very end of Trajan's empire or at the beginning of Hadrian's. Although the very existence of the capsa proves that it was a phylacterion, the lamella was not taken out from the capsa but after several years, and therefore it was mentioned in the literature only in $1950,{ }^{4}$ and the next occasion was only in $1979 .^{5}$

The word mentioned, must be taken in a literal sense; there was no proper publication, because it contained neither useful data nor any reading. A photo was attached, ${ }^{6}$ but it shows the lamella as reflected in a mirror, perhaps because a mistake occurred in the print. ${ }^{7}$ Naturally it was nearly impossible, to take a usable photo of the shining silver lamella, which was several times folded and afterwards smoothed. Consequently, nobody realized for a long time that the magical text cannot be read unless running reverse direction. Probably J. Szilágyi really thought that the text was made on the back of the lamella, because the 'old inventory' of the Museum of Aquincum (from the end of the 1940s) contains a similar mirrored drawing; however, in all probability, it was drawn independently from the photo, based on the lamella itself.

It was fatal for the first reading of the lamella, in R. Kotansky's corpus of the protective magic texts in metallic lamellas from the empire. ${ }^{8}$ Although most other objects were thoroughly interpreted by Kotansky, both in reading and their religious meaning, ${ }^{9}$ in this case, we must abandon his whole interpretation, because it was done based on the mirrored photo, in lack of autopsy, ${ }^{10}$ and so he read the following letters:

\footnotetext{
${ }^{3}$ Szilágyi 1950, 321, note 66 gives the date as AD 116; Németh 2005, 89, follows him. According to Szilágyi's description, we cannot state the date with such accuracy, but AD 114-117 (cf. RIC II 267, nr. 326).

${ }^{4}$ Szilágyi 1950, 319.

${ }^{5}$ Bilkei 1979, nr. 19, only another mention. The author inserted the object into an epigraphical corpus, with a separate catalogue number, but she did not read the text. Similarly the catalogue of the Museum of Aquincum did not read it in 1995: Csontos 1995, 51, nr. 215 (fig. 68).

${ }^{6}$ Szilágyi 1950. fig. 28 (p. 321). It is characteristic for the 'accuracy' of Szilágyi's essay, that the list of figures in Russian (p. 325) gives the figure number 27 (mentioning a photo of the capsa too, which does not exist), while the same list in a French version (p. 331) the number 29.

${ }^{7}$ The first researcher, who noticed it, was György Németh: Németh 2005, 90, Németh 2006, 49.

${ }^{8}$ Kotansky 1994, 91-92, nr. 20.

${ }^{9}$ As the lamella of Ságvár in the nearest part of Pannonia Inferior, which bears some resemblances to our lamella too, ibid. 81-88, nr. 18 .

${ }^{10}$ Naturally it was the reason why he had to make the statement: 'very little of this corroded piece can be read'. However, the facts are otherwise. The silver lamella is not corroded, and not
} 


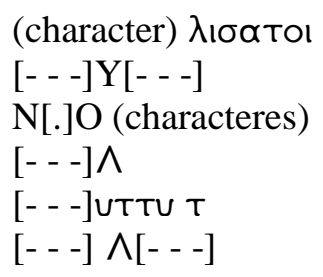

This interpretation begins with a meaningful Greek word, normalized as $\lambda$ ú́ate. It was problematic in some way: the development ol $>\varepsilon$ appears very early, since the text was written in the latest Trajan or (early) Hadrian era Kotansky did not specify the date more exactly than the 2 nd c., but I take the good condition of the coin into account -, and this is unparalleled in the Danube region. ${ }^{11}$ On the other hand, if verse 1 was meaningful, we may suppose verse 5 was too, being not a sequence of characteres according to his drawing; yet the letters UTTU $\mathrm{T}$ could not be deciphered. ${ }^{12}$

The lamella was first re-read and re-interpreted by György Németh, ${ }^{13}$ who tried to give a coherent new reading of the whole, based on the text itself and not a (mistaken) photograph. He realized the right direction and discerned characteres and magical words, but part of the lamella remained sequence of letters that cannot be interpreted.

His reading:

\section{$\mathrm{U}[\ldots] \mathrm{C}$ (characters) FDD $\alpha v o \chi$ \\ avox (?) \\ (character) $k 3 \mathrm{OOIH}$}

$$
\begin{aligned}
& \delta o ́[s] \mu \mathrm{l} \\
& \text { חור אור - - - - }] \Delta[- \text { - - }
\end{aligned}
$$

\footnotetext{
in a hopeless condition in three quarters, save for a few breaks in continuity. It was correctly unfolded, so the surface is the nearest possible to plain.

${ }^{11}$ A development $u>1$ occurs sporadically in the middle Danubian provinces (Pannonia: cf. the data of CIGP, and the linguistic analysis which exists regrettably only in the second edition of this corpus: CIGP ${ }^{2}$ 66-68; Dacia: Ruscu 2003), but it might be influenced by the Latin language (Fehér 2007, 452, note 8). The Greek ol developed into $v$ in this region, but in the later eras (4th c.): Fehér 2007, 362-363.

12 ، ....unless we are to understand this as Latin tuta.' Kotansky, loc. cit.

${ }^{13}$ Németh 2005, and a little modified, Németh 2006.
} 
Since then, nobody challenged his interpretation practically. ${ }^{14}$ According to this interpretation, the magical text was composed of three or four elements: $a$ ) characteres, an incoherent sequence of letters and signs from diverse alphabets (verses 1. and 3.), b) a meaningful Greek text (verse 4.), c) a likewise meaningful Hebraic text, the first word of which runs reversely (correctly רוח), and $d$ ) in verses 1 . and maybe 2. a group of Greek letters which gives, according to him, the Coptic word anox. This was a quite plausible hypothesis in itself. Such alternation of writing systems is fairly well known in magical texts. However the text seemed to be amorphous: one could not divide it into structural units and could not observe what the amulet was meant to avert and which numen it invoked. The repeated unidentifiable signs (in what Németh edited as verse 4) were undecipherable too.

Formerly I proposed a little modification, ${ }^{15}$ that is the only backward running word should be read in a usual direction as חרו 'Horus'. So we may know one invoked numen at least. Certainly this modification is not inevitably necessary, because it is not unusual that only a part of the magical text runs reversely, or even reversed and upside-down letters are alternating without a visible system. ${ }^{16}$ Nevertheless, we have not encountered reversed writings on phylacteria in Pannonia till now, but in curse tablets; it is unclear whether it had any special offensive nature or not. Moreover it is hard to judge which text is retrograde in a ritual sense, because it means not only reversed or upside-down letters and words, but those written with instruments reversely held in one's hand; these can be identified only if the letter forms are radically changed within the text. There is a textual reference to it from Aquincum, where the writer states that he is writing with a style turned away with the intention of turning away the maleficent tongues. ${ }^{17}$ In the actual locus, the method is meant to be offensive, as a curse, but with the same reasoning it might be apt for a defensive amulet, to turn away the demons.

\footnotetext{
${ }^{14}$ The new catalogue of the Museum of Aquincum is based on Németh's edition: Zsidi 2009, nr. 1130.

${ }^{15}$ Fehér 2007, 66, I 1.4.4.2.

${ }^{16}$ For example Hoffiller - Saria 1938, nr. 432 (a Latin-speaking curse tablet).

${ }^{17}$ Barta 2009 = TitAq 1436, vv. 10-13: Eo modo hoc ego averso graphio scribo, sic linguas illorum aversas ne possint facere contra hos. Barta - Lassányi 2009 interpret the text with these words: 'I write with a style diverted from its purpose, far from everything' (translation by me. B. F.), but this interpretation itself is far from everything meaningful and logical. They virtually maintain their interpretation in their recent article (Barta - Lassányi 2015) with a slight modification, in spite of my refutation in TitAq 1436 (III 156. p.). It is clearly visible that the first verse of the curse tablet was written in a regular, easily legible handwriting, and all the following with smaller, distorted letters. This marks the point where the author changed his hand to an unnatural one.
} 
The Coptic word was hard to identify in the published photo, but there were other elements too which referred to Egypt as a religious background, most inevitably the hieroglyph $k 3$ which was the main novelty in Németh's publication. In sum, the amulet did not seem problematic, and my re-examination was only a part of the routine research of the $\mathrm{CIL}^{2}$ edition of the inscriptions in Pannonia, ${ }^{18}$ not in hope of a new interpretation.

Surprisingly, I found a profoundly new reading by autopsy, and now the structure of the text is clear, its structural units can be identified.

The size of the silver lamella is $7,8 \times 8,0 \mathrm{~cm}$, it was put into the capsa vertically folded up into six strips. (A secondary folding is visible on the right side, dividing the right part into halves. ${ }^{19}$ ) The whole was folded once more horizontally. Regrettably, several parts were broken out along the foldings. There is a conspicuous gap below on the right. The horizontal folding did not damage the text very much, because it was clearly divided into two major sections with no writing in the middle, but the sections were separated with a sequence of eight semicircular ornamental patterns. Verse 4 virtually does not exist, as it was supposed by Gy. Németh, part of it being the ornamental pattern, part of it the lesions of the folding, but a doubtless delta remains at the initials of the verse, closely under the semicircular pattern. It is evidently a character, since it is not connected with any other textual element.

The position of the character shows, that the text does not run systematically reversely (although sporadical reverse characters are not impossible); on the other hand, we may expect initial characteres before the textual units. Indeed where verse 1 begins, there is a character bigger than the others, either a $\mathrm{Z}$ reverse and crossed out, or an archaic yod. ${ }^{20}$

Both parts of the text contain three verses (in sum, seven with the middle character). The lowest section is almost illegible, mutilated and rumpled, but three quarters of the text are legible, revealing a clear structure, but containing different elements from what was supposed until now. The correct reading is: ${ }^{21}$

\footnotetext{
${ }^{18}$ It is a project going on from 2004; the material of Aquincum and Savaria was wholly republished (TitAq I-III, Tóth 2011). Several reports were published, how the project was proceeding: Kovács 2008, Kovács 2012, Kovács 2013.

${ }^{19}$ In Kotansky's opinion it was folded three times, which gave in sum eight strips. Németh thinks that the nine fold folding (in sum) was made from magical reasons, in connection with the character kA (Németh 2006, 50). It is not impossible, but I do not think it likely, because the last threefold folding was secondary.

${ }^{20}$ This interpretation was proposed by Philonenko 1979, 301, when the text refers to IAW/Abraxas.

${ }^{21}$ Previously published: TitAq III nr. 1437.
} 
(character) 'I $\omega \dot{\omega} \pi \alpha \chi \underline{0} \mathrm{of}$

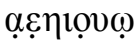

(character) (character) OOṆN

(character)

5 חרו אור

$+[.] \Delta+[.] \Delta[---]$

$[---] \Lambda[---](?)$

We can discern these textual units:

a) a character followed by a possibly continuous text in Greek letters and a series of vocals (verses 1-2),

b) characteres followed by a known short Greek magical word (verse 3) and a major break,

c) a character followed by the text in Hebraic letters, and a cross, which seems to be no letter but a bigger and more negligently scratched mark (verses 4-5),

d) scarcely legible Greek letters (verses 6-7); the major part of the first letter was broken out, but it may have been a character too.

It is necessary to put an entirely new interpretation on Unit a) The opening character seems to invoke the supreme deity; the following $I \omega$ sequence speaks for that, because it is probably a shorter form of the widely known invocation IA $\omega .^{22}$ Although IAW is nothing else but a Greek transcription of יהוה, we cannot know for certain, who was meant to be the supreme deity: this magical word, used far and wide, appears often in non-Jewish contexts too, as an epitheton of Abrasax ${ }^{23}$ or other magical powers, or even referring to Zeus. ${ }^{24}$ Verse 2 contains the well-known magical series of vowels (but the lamella was so much damaged in these parts that it could be read only because the series is so well known). On one hand, it can be an amplified representation of the word IA $\Omega$,

\footnotetext{
${ }^{22}$ A different interpretation: Kotansky 1994, 96, nr. 23; Kotansky - Faraone 1988, 264. They take it for a classical Greek invocative interjection (not all of their examples are real). However one cannot deny that it occurs together with the characters IA (יה ) mostly related to Sabaoth (typical examples are Audollent 1904, nr. 252 v. 20, 253 v. 30, Kotansky 1994, nr. 7 (where a series of IA and another of I $W$ encircle the word Sabaoth, evidently with the same function), Ruscu 2003, 45 with a retrograde $\omega I$ and a variant IY 'A $A(\omega) \nu \propto(i)$.

${ }^{23}$ A short comprehensive study: Nagy 2004.

${ }^{24}$ An equivalence of Zeus and Adonai: see LiDonnici 2007, 102. It is the more interesting

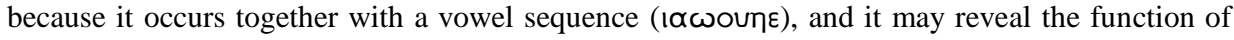
the character Z/Yod in the Aquincum lamella.
} 
itself a shorter vowel sequence; on the other hand, it displays the magical power of the alphabet. ${ }^{25}$

These two elements encircle a longer word, which is hard to explain; nevertheless it is sure that it cannot be anox, as Gy. Németh proposed: there is something between the letters A and $\mathrm{N}$, and the last letter is definitely not a X). The correct reading is $\Pi A X N O F$. It is a word which can be explained only in a Coptic context: $\pi \alpha \times$ voupu (that is, maxvoupis). It occurs in a curse tablet too, ${ }^{26}$ in a name list among various powers or demons. In the present situation, it seems to hold a more important position: the structure of the amulet points to that it must be invoked as a supreme deity, and it had a definite protective function.

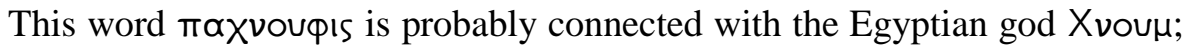
it is not alien from the whole context of the phylacterion, since Xvou $\mu$ had an aspect of regeneration, especially in the form Chnuph Harpenknuphi known from the later magical literature, identified with Horus Haroeris. ${ }^{27}$

Unit b) opens with two characteres, the second one being a roughly regular hieroglyph, namely $k$, as Gy. Németh has already identified it. ${ }^{28}$ The first one can be identified as well: 3ht. Their accurate drawing reveals that the author was relatively well versed in magic. We can hardly find any coherence with the following word OON. It is not evident how it must be interpreted $;^{29}$ however, it certainly refers to an invoked numen. By the way, this word was known in Pannonia, on a bronze lamella of preventive nature ${ }^{30}$ we may suppose it was relatively well-known, used in a wider circle, not only in a special context.

Unit c) contains Hebraic letters (or imperfect imitations), which betray the author's lack of skill, or inaccurate copying. The letters seem to construct a con-

\footnotetext{
${ }^{25}$ It is a long-debated question whether any magical power can be attributed to the alphabet or not; for my part, I am of the opinion that a restricted magical use cannot be denied (see recently Gabler 2013, 165 with a selected previous literature, contra Fehér 2013, 179).

${ }^{26}$ Audollent 1904, 270, 15.

חרו אור ${ }^{27}$ Bonnet 1952, 139-140. - Perhaps one might propose a transliteration of the letters of verse 5 as Haroeris?

${ }^{28}$ Németh 2006, 50

${ }^{29}$ Kotansky's interpretation (Kotansky 1994, nr. 41 v. 36): it refers to the supreme deity $(o \omega v)$. There the word is inserted among the names of subordinate (angelic) powers, thus his interpretation does not seem too likely, at least in that same locus. Another probability is the equivalence with the formula oovou = Tò övoua, which is naturally a paraphrase of the name of the invoked deity.

${ }^{30}$ CIGP 152., among demonic or angelic names (the context suggests an uncertain Jewish

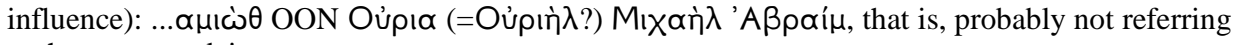
to the supreme deity.
} 
tinuous text, but only the vertical stems are certain, which are only mechanically connected with horizontal strokes. It shows that he who wrote it, was not an expert of Hebraic scripture, ${ }^{31}$ while he produced tolerably correct CopticEgyptian motives, and consequently probably knew their ritual significance. We can decipher the letter either as חור אור אור, or as מור אור, both expressions fit into the context, because the word אור 'light' is connected with the hieroglyph 3 ht which the previous unit begins with. If we read the word רוח 'spirit', it is obvious to interpret it as the translation of the hieroglyph $k 3$ (then the author must have understood the literal meaning of the characteres); yet the word Horus is not impossible either, it has its meaning together with the hieroglyph $3 \mathrm{ht}$ as a Horus identified with Ra.

The meaning of the character $\Delta$ remains still unclear, together with the question, why the second half of the following verse was left vacant after a cross thinly scratched in.

There is another question still to be answered. What did this amulet defend from? It was found in a funerary context together with a coin, therefore there is an obvious possibility that it was a funerary amulet which gave protection in afterworld. Gy. Németh rejects this possibility: he argues that the owner carried an amulet further on in the sepulchre, which he had worn in life hoping to avert a definite threat, probably an illness. ${ }^{32}$ But we cannot conclude to any exact disease from the text, neither named nor deduced from the properties of the averting deity. The hieroglyphic characteres allude rather to the next world. If we read the Hebraic text as a reference to Horus, we must suppose the invocation of a numen with an aspect of regeneration; if we take it as an affirmation of the $k$, the power of the phylacterion evidently refers to the defence of the soul after death. Consequently, my opinion is that this lamella must be interpreted as a protective one not in this world but in the other, ${ }^{33}$ composed with an unusual accuracy and professionalism. Further researches of this amulet may be useful too, since no matter how damaged the last two verses are, the consequent structure and professional contents give us hope that their deciphering and interpretation may be successful too.

\footnotetext{
${ }^{31}$ Németh 2005, 95, Németh 2006, 51: the only certain information of the writer is that he was a Jew. In my opinion, it is quite uncertain. The numerous Jewish elements of magical text generally do not refer to a real Jewish origin but some Jewish-like allusions, even as we may think the same of the Egyptian elements: comprehensively see LiDonnici 2007.

${ }^{32}$ Németh 2006, 50 .

33 There are some similar examples: Kotansky 1994, nr. 27, 23 (the latter one was found in the same Danube region, although from a later period, and there is a slight similarity in their composition too).
} 
Fig. 1: photo of the lamella of Aquincum (2009)

2. drawing of the text (2009)

\section{Bibliography}

Audollent 1904 = Augustus Audollent, A.: Defixionum tabellae quotquot innotuerunt tam in Graecis orientis quam in totius occidentis partibus. Lutetiae Parisiorum.

Barta 2009 = Barta, A.: The Language of Latin Curse Tablets from Pannonia: A New Curse Tablet from Aquincum. AAntH 49.

— 2012 = Barta, A.: Milites magistratusque: A New Curse Tablet from Savaria. ACD 48, $167-$ 173.

— 2016 = Barta, A.: Ito Pater, Eracura és a kézbesítő: Előzetes jelentés egy újabb aquincumi átoktábláról (I. P., Eracura and the Messenger. A Preliminary Report on a New Curse Tablet from Aquincum. AntTan 60, 81-91.

Barta - Lassányi 2009 = Barta, A. - Lassányi, G.: Sötét fohászok. Gondolatok a római átokszövegekröl egy új aquincumi ólomtábla kapcsán (Dark Supplications. Reflections on the Roman Curse Texts on the Pretext of a New Lead Tablet from Aquincum). Ókor 8/3-4, 63-69.

- 2015 = Barta, A. - Lassányi, G.: Az elgörbült nyelv. Új adatok egy aquincumi átoktábla rítusához (The twisted language. New data to the Rite of a Curse Tablet from Aquincum). Ókor 14/1, 70-74.

Bilkei 1979 = Bilkei, I.: Die griechischen Inschriften des römischen Ungarns. AlbaRegia 17, 23-48.

Bonnet 1952 = Bonnet, H.: Reallexikon der ägyptischen Religionsgeschichte. Berlin.

CIGP = Kovács, P.: Corpus Inscriptionum Pannonicarum. HPS 8, Debrecen 2012, 66-68; HPS 15, Budapest 2013.

Csontos 1995 = Csontos, K.: Tárgykatalógus (Catalogue of objects). In: Zsidi, P. (ed.): Istenek, katonák, polgárok Aquincumban (Gods, soldiers, citizens in Aquincum). Budapest.

Fehér 2007 = Fehér, B.: Pannonia latin nyelvtörténete (The history of the Latin Language of Pannonia). Budapest.

— 2013 = Fehér, B.: Válasz Gabler Dénes, Gesztelyi Tamás és Havas László opponensi véleményére (Reply to the Report of the Opponents D. G., T. G. and L. H.). SEP 51, 176-180

Gabler 2013 = Gabler D.: Report of the opponent on the dissertation of Bence Fehér (The inscriptions of instrumentum domesticum of Aquincum). SEP 5, 161-166.

Hoffiller - Saria 1938 = Hoffiller, V. - Saria, B.: Antike Inschriften aus Jugoslavien I. Noricum und Pannonia Superior. Zagreb.

Kotansky 1994 = Kotansky, R.: Greek Magical Amulets. The Inscribed Gold, Silver, Copper and Bronze Lamellae. Part I, Published Texts of Known Provenance. Papyrologia Coloniensia XXII/1. Opladen.

Kotansky - Faraone 1988 = Kotansky, R. - Faraone, Chr. A.: An Inscribed Gold Phylactery in Stamford, Connecticut. ZPE 75, 257-266.

Kovács $2008=$ Kovács, P.: Kutatási beszámoló (Research Report) SEP 1, 7-22.

— 2012/13 = Kovács, P.: Alföldy Géza és a CIL III2 Pannonia projekt (A. G. and the CIL III2 Pannonia project, SEP 4, 43-50 = Géza Alföldy und CIL III2. Auch ein Beitrag zum Thema: Géza Alföldy und Ungarn. In: Eck, W. - Fehér, B - Kovács, P. (eds.): Studia Epigraphica in memoriam Géza Alföldy. Bonn 2013, 121-130.

Kovács - Szabó 2006 = Kovács, P. - Szabó, Á.: Újabb latin feliratos átoktábla Pannoniából (A Recent Latin Epigraphic Curse Tablet from Pannonia. FolArch 52, 49-55. 
LiDonnici 2007 = LiDonnici, L.: "According to the Jews": Identified (and Identifying) 'Jewish' Elements in the Greek Magical Papyri. In: LiDonnici, L - Lieber, A. (eds.): Heavenly Tablets. Interpretation, Identity and Tradition in Ancient Judaism. Leiden, 87-108.

Nagy 2004 = Nagy, Á. M.: A kakasfejü-kígyólábú istenalak - ábrázolható-e az Ábrázolhatatlan? (Cock-headed and Serpent-legged God Figure - Is to Represent the Unrepresentable?). Ókor, $3 / 3,67-72$.

Németh 2005 = Németh, Gy.: A Magic Silver Lamella from Aquincum. In: Németh, Gy.: Politai. Studies in Greek Social History and Epigraphy. Debrecen, 89-97.

- 2006 = Németh, Gy.: K3 Aquincumban. Egy mágikus amulett feliratának értelmezése (K3 in Aquincum. The Interpretation of the Inscription of a Magical Amulet. Ókor 5/2. 49-52.

Philonenko 1979 = Philonenko, M.: L'anguipède alectorocéphale et le Dieu Iaô. Comptes-Rendus de l'Académie des Inscriptions 123, 297-304.

RIC = Mattingly, H. - Sydenham, H. E. A. et alii (eds):The Roman Imperial Coinage . London 1923-2007.

Ruscu 2003 = Ruscu, L.: Corpus Inscriptionum Graecarum Dacicarum, HPS 10. Debrecen.

Szilágyi 1950 = Szilágyi, J.: Jelentés a fővárosi ókortörténeti (aquincumi) múzeum kutatásairól és szerzeményeiről az 1945-48 évek folyamán, (Report on the Researches and Acquisitions of the Metropolitan Museum (Ancient History, in Aquincum) During the Years 1945-48. BudRég 15, 303-331.

TitAq = Kovács P. - Szabó Á. (eds.): Tituli Aquincenses I-II, Fehér B. (ed.) III, Budapest 2009_ 2011.

Tóth 2011 = Tóth, E.: Lapidarium Savariense. Savaria római feliratos köemlékei (Inscriptional Stone monuments of Roman Savaria). Szombathely.

Zsidi 2009 = Zsidi, P. (ed.): Aquincumi Látványraktár: a BTM Aquincumi Múzeuma állandó kiállitásának katalógusa (Visual Store at Aquincum: Catalogue of the Permanent Exhibition of the Aquincum Museum. Budapest.

(ISSN $0418-453 X)$ 